\title{
Metabolites, water and mineral exchanges across the rumen wall: mechanisms and regulation*
}

\author{
D Rémond ${ }^{1}$, $F$ Meschy ${ }^{2}$, $R$ Boivin ${ }^{3}$ \\ 1 Station de recherche sur la nutrition des herbivores, \\ Centre Inra de Theix, 63122 Saint-Genès-Champanelle; \\ 2 Laboratoire de nutrition et alimentation, Inra Ina-PG, 78352 Jouy-en-Josas; \\ ${ }^{3}$ Service de physiologie, ENV de Lyon, 69280 Marcy-l'Étoile, France
}

(Received 14 February 1995; accepted 16 August 1995)

\begin{abstract}
Summary - In ruminants, the forestomachs, and especially the reticulorumen, have walls with anatomical and histological properties that permit the exchanges of various metabolites, water and minerals between the rumen contents and the blood. The development of papillae on the walls and the local blood circulation favour these exchanges. They depend to varying degrees on the food supply and the concentrations of volatile fatty acids (VFA) produced by the microbial catabolism of polysaccharides. The absorption of VFA and ammonia occurs essentially by a process of passive diffusion of their nonionised form through the epithelial cell membranes. For each of these substances, the existence of a transport system for the ionised forms is also suspected, but its relative importance is unknown. Shortterm modifications in the absorption of these two substances are thus primarily determined by variations in their intraruminal concentrations and $\mathrm{pH}$. Other factors may also be implicated, and it is known in particular that the absorption of ammonia is enhanced when the intraruminal concentration of VFA or the carbon dioxide $\left(\mathrm{CO}_{2}\right)$ level increases. The movement of urea through the wall occurs from the blood towards the rumen content according to the concentration gradient. The main factors liable to influence the transepithelial flux of urea seem to be the blood urea levels and factors that act on the contact surface between the blood compartment and the epithelium $\left(\mathrm{CO}_{2}\right.$, VFA). Ruminal ammonia concentration also affects the net urea transfer across the rumen wall but the mechanisms involved in this regulation are not clearly understood. The absorption of water through the rumen wall results from an osmotic pressure gradient between the rumen and the plasma. This is modified not only by factors that modify the blood flow rates at the wall, but also by electrolyte concentrations. The absorption of minerals from the rumen has also been demonstrated ( $\mathrm{Mg}, \mathrm{Ca}, \mathrm{Na}, \mathrm{Cl}, \mathrm{K}$, sulphur and certain metals). This occurs by mechanisms of varying complexity according to the element involved.
\end{abstract}

rumen wall / volatile fatty acid / ammonia / urea / water / minerals

\footnotetext{
* Report presented in the 9th Conference on Nutrition and Feeding of Herbivores, Clermont-
} Ferrand, France, 16-17 March 1994. 
Résumé - Échanges de métabolites, d'eau et de minéraux à travers la paroi du rumen : mécanismes et régulations. Chez les ruminants, les préestomacs, et plus particulièrement le réticulorumen, ont une paroi dont les caractéristiques anatomo-histologiques permettent les échanges de différents métabolites, d'eau et de minéraux entre le contenu ruminal et le sang. Le développement des papilles de la paroi et l'importance de l'irrigation sanguine favorisent cette absorption et sont plus ou moins dépendants des apports alimentaires et de la concentration en acides gras volatils produits par le catabolisme microbien des polysaccharides. L'absorption des acides gras volatils et de l'ammoniaque s'effectue essentiellement selon un processus de diffusion passive de leur forme non ionisée à travers les membranes des cellules épithéliales. Pour chacune de ces substances, l'existence d'un système de transport pour les formes ionisées est également suspectée, mais on ne connait pas l'importance relative de cette voie de passage transmembranaire. Les modifications à court terme de l'absorption de ces deux molécules sont donc en premier lieu déterminées par des variations de concentration intraruminales et des variations de $\mathrm{pH}$. D'autres facteurs peuvent également intervenir et on sait notamment que l'absorption d'ammoniaque est accrue lorsque la concentration intraruminale en acides gras volatils ou la teneur de $\mathrm{CO}_{2}$ augmente. Le passage d'urée à travers la paroi s'effectue du sang vers le contenu ruminal en fonction du gradient de concentration. L'urée étant rapidement et totalement hydrolysée dans le rumen, les principaux facteurs susceptibles de faire varier ce flux transépithélial d'urée semblent être l'urémie et les facteurs agissant sur la surface de contact entre le compartiment sanguin et l'épithélium $\left(\mathrm{CO}_{2}\right.$, acides gras volatils). La concentration ruminale en ammoniaque joue également un rôle dans la régulation du transfert d'urée ; son mode d'action n'est cependant pas clairement déterminé. L'absorption d'eau à travers la paroi du rumen résulte d'un gradient de pression osmotique entre le rumen et le plasma ; elle est modifiée, non seulement, par les facteurs qui modifient le débit sanguin au niveau de la paroi, mais également par les concentrations en électrolytes. Les minéraux peuvent également être absorbés à travers la paroi du rumen $(\mathrm{Mg}, \mathrm{Ca}, \mathrm{Na}, \mathrm{Cl}, \mathrm{K}$, soufre et certains métaux); cette absorption s'effectue par des mécanismes plus ou moins complexes et son intensité est variable selon l'élément considéré.

paroi ruminale / acide gras volatil / ammoniaque / urée / eau / minéraux

\section{INTRODUCTION}

The development of voluminous forestomachs, and in particular the development of the reticulorumen, gives ruminants a highly characteristic digestive physiology. Certain aspects of this digestive physiology are well known. Numerous studies have been devoted to the motricity of the reticulorumen, its regulation and its effects on digestive transit. Likewise, the biochemical aspects of microbial digestion and its consequences for nutrition and metabolism in ruminants have been thoroughly studied. In contrast, the extent to which the reticulorumen is able to absorb and recycle materials through its wall is less well known. It was long assumed, as stated by Colin in 1853, that "the epithelium of the rumen is less permeable than that of the mouth and oesophagus, and is without doubt the main obsta- cle to absorption in the first stomach compartments". Although it is now well established that the mucosa of the reticulorumen possesses an absorptive function, it is only in recent years that significant progress has been made in the quantitative evaluation of the absorption processes, through the use of isotopic dilution techniques that allow nitrogen flow rates to be estimated (Nolan and Leng, 1972), and the development of methods for ruminal blood flow measurement and ruminal vein catheterisation (Rémond et al, 1993c), which make it possible to measure net fluxes of metabolites across the ruminal wall. The parallel use of in vitro techniques (Martens et al, 1978) has generated essential information for understanding the mechanisms involved in these transepithelial transport processes.

For certain substances derived from microbial metabolism or present in the feed, 
the rumen can represent the most important absorption site in the digestive tract (VFA, ammonia, magnesium, etc). The quantitative extent of this absorption depends primarily on the absorption capacity of the rumen, which is determined by the structure of the epithelium and the amount of exchange surfaces between the digestive contents and the blood. It also depends on the mode of transport specific to each substance.

\section{MORPHOLOGICAL AND FUNCTIONAL CHARACTERISTICS OF THE RUMEN WALL}

\section{Structure of the ruminal mucosa}

The reticulorumen is a highly voluminous compartment ( 80 to $100 \mathrm{~L}$ in the cow, 10 to $15 \mathrm{~L}$ in the sheep). It is subdivided into several compartments by various folds of its wall, which has the effect of increasing the amount of surface area contacting the digesta. The surface area of the rumen mucosa is further increased by the presence, over practically the entire inner wall, of numerous conical or tongue-shaped papillae. The distribution, size and number of these papillae depend on the species and also on diet. In cattle, 80 to $85 \%$ of the inner surface are covered with papillae; in sheep, the papillae are irregularly distributed, and the ruminal pillars and the dorsal sac are usually devoid of papillae, or bear papillae of small size. The differentiation of papillae observed in different parts of the rumen appears to be linked to the layering of the digestive contents in the rumen.

The papillae, as well as the entire inner rumen wall, are covered with a mucous membrane composed of a keratinised multilayer epithelium, a richly vascularised conjunctive tissue, crossed by nerve fibres and lymph ducts, and a fine layer of smooth muscle separating the mucosa from the underlying tissues.

The epithelium is formed of four cell layers: the stratum basale, the stratum spinosum, the stratum granulosum and the stratum corneum (Steven and Marshall, 1970). The cells of the stratum basale appear to be the most metabolically active since they contain numerous mitochondria and free ribosomes. A large proportion of the assimilation and metabolism of the substances absorbed from the rumen may thus occur in this cell layer. It is here that the cell division takes place. Thereafter, the cells differentiate as they migrate towards the stratum corneum.

According to Steven and Marshall (1970), the fusion of the cell membranes (tight junctions) in the stratum granulosum leads to an obliteration of the intercellular spaces and thus causes this cell layer to act as a barrier controlling the movement of materials between the blood and the rumen. The presence of this barrier in the stratum granulosum was not, however, observed by Henrikson (1970), and Henrikson and Stacy (1971) later observed that the barrier to diffusion through the epithelium of different markers was located in the inner layers of the epithelium corneum. According to these authors, the selective permeability of the epithelium may be explained by the coating of mucopolysaccharide on the keratinised cells, and by the succession of different types of membrane junctions (desmosomes, tight junctions) beneath the cornified layer, rather than by an actual barrier in the stratum granulosum.

The stratum corneum is made up of keratinised cells (the cell nuclei have vanished). The keratinisation of the surface layer protects the mucosa against the abrasive action of the rumen contents and the penetration of microorganisms. Although intercellular spaces are once more visible in this layer, they are sufficiently narrow to prevent bacteria from passing through (Steven and Mar- 
shall, 1970). The biosynthesis of keratin in the epithelial cells during their movement from the stratum granulosum to the stratum corneum is accompanied by a decrease in cell permeability (Fell and Weekes, 1975). The keratin formed softens, however, to some extent, on contact with the rumen contents, which should make it more permeable. The stratum corneum of the epithelium is thus a complex system containing both strongly keratinised cells that offer a high resistance to abrasion, and partly keratinised mucus-producing cells with absorptive capacity (Sydney and Lyford, 1988).

The efficiency of nutrient transport across the epithelium thus depends to a large extent on the integrity and degree of keratinisation of the stratum corneum. This layer can display various anomalies: parakeratosis, which leads to an incomplete keratinisation of the cells of the stratum corneum and a disappearance of the stratum granulosum, or hyperkeratosis, characterised by excessive thickening of the stratum corneum, sometimes associated with a thickening of the stratum granulosum.

The thickness of the ruminal epithelium depends on the rate of cell division in the basal layer of the epithelium, the speed of migration of the cells from the deep layers to the surface layers, and the rate of cell shedding from the stratum corneum. Many studies have been conducted on the regulation of cell proliferation in the epithelium (Galfi et al, 1991). It is known that the mitotic activity of the epithelium can be depressed by fasting, and restored by the subsequent refeeding (Tamate et al, 1974). In addition, it is very strongly stimulated by intermittent feeding (Sakata and Tamate, 1974). Injection of acetate, butyrate and propionate into the rumen stimulates the proliferation of epithelial cells in fasting sheep (Sakata and Tamate, 1978, 1979). Butyric acid has a stronger stimulating effect than either propionic or acetic acid. The replacement of a forage-based diet by one based on con- centrate also causes a rapid rise in the mitotic index of the ruminal epithelium (Goodlad, 1981). Diets that produce an abundant production of VFA with a high proportion of butyric acid are considered, therefore, to be promotors of cell proliferation in the rumen.

The structure of the epithelium is also affected by the rate of cell shedding from the surface layers of the epithelium. According to McGavin and Morrill (1976), the grating effect of rough forage is necessary to prevent an excessive accumulation of keratinised cells at the surface of the ruminal mucosa. The abrasive action of the rumen contents thus plays an important role in the rate at which cells are shed from the stratum corneum. The contribution of adhering bacteria colonising the surface cells of the epithelium should not, however, be underestimated. Their action can accelerate the breakdown of keratinised cells, and thereby their shedding (Cheng and Costerton, 1980). The distribution of these bacteria at the surface of the ruminal epithelium indicates that they are also affected by food abrasion (McCowan et al, 1980). The breakdown of epithelial tissue by bacteria may thus be more efficient at locations where the rumen wall is less affected by physical erosion.

The lumen surface area of the epithelium can vary widely according to the number, size and shape of the papillae that develop on the inner surface of the rumen. When the diet is changed, the morphological adaptations of the ruminal epithelium are rapid ( 2 to 3 weeks), and are particularly evident in the atrium. In adult ruminants, the mass of the mucosa increases linearly with the amount of food ingested daily (Fell and Weekes, 1975). This weight increase is accompanied by an increase in the length of the papillae. The diet can also modify the shape and number of these papillae. A diet rich in concentrate, generally associated with high concentrations of VFA in the rumen, results in a stronger development 
of rumen papillae than is observed with a diet based on forage (Wiegand et al, 1975). Gabel et al (1987) observed that the outer surface of the ruminal papillae can be increased by 200 to $400 \%$ by a change from a hay-based diet to one containing 64 to $90 \%$ concentrate.

The inner surface area of the epithelium also varies according to the development of the mucosa (Tamate and Sakata, 1979). For a ruminal mucosa with well developed papillae, the basal membrane of the epithelium is not flat and parallel to the outer surface of the epithelium, but displays irregularly-sized folds. These increase the surface area of the epithelium-conjunctive tissue interface and reduce the effective thickness of the epithelium. This type of interface is associated with well developed papillae known to be very important sites of absorption (Tamate and Sakata, 1979).

In summary, the ruminal epithelium responds to an increase in ingested food quantities, an increase in levels of highly fermentable substrates in the rumen, and to any other factor that induces an increase in VFA production (especially butyrate), by a change in the number and shape of the papillae present on the walls, accompanied by an increased proliferation of basal layer cells, which causes an increase in the surface area of the epithelium-conjunctive tissue interface. These structural modifications of the epithelium result in an increase of the luminal surface area of the rumen wall, and an increase in the exchange surface between the capillaries and the epithelium, thereby giving the rumen a higher absorption capacity.

Diets rich in concentrate often result in hyperkeratosis of the epithelium. The thickening of the stratum corneum may result in lowered nutrient absorption rates (Nocek et al, 1980) and the increase in the absorption surface area observed with this type of diet would then act as a corrective to the hyperkeratinisation in order to maintain the absorptive capacity of the epithelium (Sydney and Lyford, 1988). Thorlacius and Lodge (1973) even observed an increase in the VFA absorption through the rumen wall despite an apparent hyperkeratinisation.

\section{Irrigation of the rumen wall}

The ruminal mucosa is richly vascularised and presents a complex network of anastomosed vessels in the subepithelial conjunctive tissue (Cheetham and Steven, 1966). The basal layer of the epithelium is in contact with a dense network of capillaries, and loops of capillaries also run through the folds at the interface of the epithelium and the conjunctive tissue of the ruminal papillae. The presence of vascularisation in these folds can double the exchange surface between the capillaries and the interstitial tissue relative to the lumen surface of the epithelium (Cheetham and Steven, 1966).

The rate of rumen blood flow can vary widely according to the ruminant's feeding pattern and diet. Throughout a feeding cycle it may account for 15 to $40 \%$ of the blood flow in the portal vein (Barnes et al, 1983). For sheep fed one meal per day, the blood flow rate could multiply by three or four between the beginning and the end of the meal (Barnes et al, 1983; Rémond, 1992). This increase in flow rate during ingestion depends on the amount of dry matter ingested; when the same amount of feed is split up into 16 daily meals, these flow rate variations fall to about 35\% (Rémond, 1992). The rumen blood flow also increases during rumination, but far less markedly (Rémond, 1992; Méot and Boivin, 1994). It also depends on the type of diet, and probably too, on the feeding level. By supplementing a hay-based diet with starch, Rémond et al (unpublished data) observed an increase in daily ruminal blood flow of about $50 \%$. 
The injection of labelled microspheres has shown that the blood flow (per unit weight of tissue) in the ruminal mucosa is 8 to 17 times greater than in the parietal smooth muscles (Engelhardt and Hales, 1977; Barnes et al, 1983). During ingestion, the flow rate rises rapidly in the parietal muscle layers, concurrent with the increase in the contractile activity of the rumen. The subepithelial blood flow rises more gradually, and peaks only towards the end of food intake (Barnes et al, 1983). Apparently then, the blood flow in these two parietal areas is controlled by distinct mechanisms. While the blood flow in the muscle layers seems to be regulated via parasympathetic innervation, the subepithelial flow appears to be controlled locally by the end products of intraruminal fermentation, independently of innervation (Barnes et al, 1986). VFA (especially butyric acid) and $\mathrm{CO}_{2}$ are known to bring about a marked rise in the subepithelial blood flow (Dobson et al, 1971; Dobson, 1979).

Increased blood flow can raise the rate of absorption of substances through the rumen epithelium by reducing their concentrations in the interstitial space (washout effect), thereby increasing the concentration gradient between the lumen and blood. This effect of blood flow on absorption is minor for substances that require active transport processes for absorption (their movement through the epithelium is relatively independent of the concentration gradient), and for substances whose absorption is limited by their low transmembrane diffusability. In contrast, for substances that diffuse very rapidly through the epithelium, the absorption rate is closely dependent on the blood flow rate (Mailman, 1982).

In conclusion to this first section, it is evident that the permeability of the epithelium (degree of keratinisation and thickness of the cell layers) and the area of the exchange surface between the digestive compartment, the epithelium and the blood compartment, can vary markedly according to diet, and most particularly to the rate of VFA production. These adaptations of the epithelium have a marked impact on the quantitative extent of transepithelial exchange. The intensity of these exchanges, particularly for those substances that diffuse passively across the epithelium, is also affected by the subepithelial blood flow and the rumen motricity, which respectively ensure renewal of the blood and rumen contents in contact with the epithelium, thereby maintaining a high transepithelial gradient.

\section{MECHANISMS AND REGULATION OF THE TRANSEPITHELIAL MOVEMENTS OF SOME METABOLITES}

\section{Volatile fatty acids}

The microbial fermentation of polysaccharides (cellulose, hemicellulose, starch, etc) in the rumen produces mainly VFA. Depending on the food composition, this production represents 50 to $75 \%$ of the ingested metabolisable energy (Siciliano-Jones and Murphy, 1989; Bergman, 1990). The absorption of VFA, therefore, makes a very large contribution to meeting the ruminant's energy needs. VFA absorption through the rumen wall, first demonstrated by Barcroft et al in 1944 , represents 65 to $85 \%$ of the intraruminal production (Weston and Hogan, 1968; Peters et al, 1990, 1992). The variability of this proportion is chiefly accounted for by wide-ranging renewal rates for the liquid phase of the rumen contents.

The main VFA present in the rumen are acetic, propionic and butyric acids. Their molar proportions range from 70:20:10 with a hay-based diet to 50:35:15 with a concentrate diet. The VFA are weak acids with pKa values of $4.75,4.87$ and 4.81 for acetic, propionic and butyric acids, respectively. Calculations, using the Henderson-Hasselbach relation, indicate that for the $\mathrm{pH}$ val- 
ues generally observed in the rumen $(\mathrm{pH}$ $6-7$ ), more than $95 \%$ of the VFA will occur in their ionised form. Lowering the intraruminal $\mathrm{pH}$, and thereby increasing the proportion of non-ionised VFA, increases the VFA absorption rate (Dijkstra et al, 1993). As non-ionised VFA diffuse much more readily across the double lipid layer of the cell membranes than their ionised forms, it is generally considered that VFA absorption takes place mainly by simple diffusion of the nonionised form across the epithelium of the rumen (Bergman, 1990). The absorption of VFA in their ionised form cannot be ruled out, however. Using the Ussing chamber technique, Kramer et al (1994) showed that a proportion of the VFA could be absorbed in their ionised form, and that this absorption interacted with that of chloride, which is absorbed in exchange for intracellular bicarbonate. A system of electroneutral transport in which the VFA ions are exchanged with intracellular bicarbonate has already been observed in a teleostean herbivore (Titus and Ahearn, 1992). The absorption of VFA across the ruminal epithelium seems to occur, therefore, by a combination of passive diffusion of the non-ionised form and of facilitated diffusion of the ionised form (fig 1). The relative extents of these two transmembrane transport processes are not yet known. According to Titus and Ahearn (1992), for organs such as the rumen, in which VFA concentrations are high, the VFA anion transport system would only make a small contribution to the total VFA absorption, acting more as an intracellular bicarbonate excreting system.

Making the assumption that VFA are mainly absorbed by diffusion of the nonionised form, their absorption rate will depend on the concentration gradient of this form between the digestive contents and the epithelium, and between the epithelium and the blood (the three compartments involved in the absorption process). These gradients are determined by the total VFA concentration in each compartment, and by the $\mathrm{pH}$, which governs the equilibrium between the ionised and non-ionised forms.
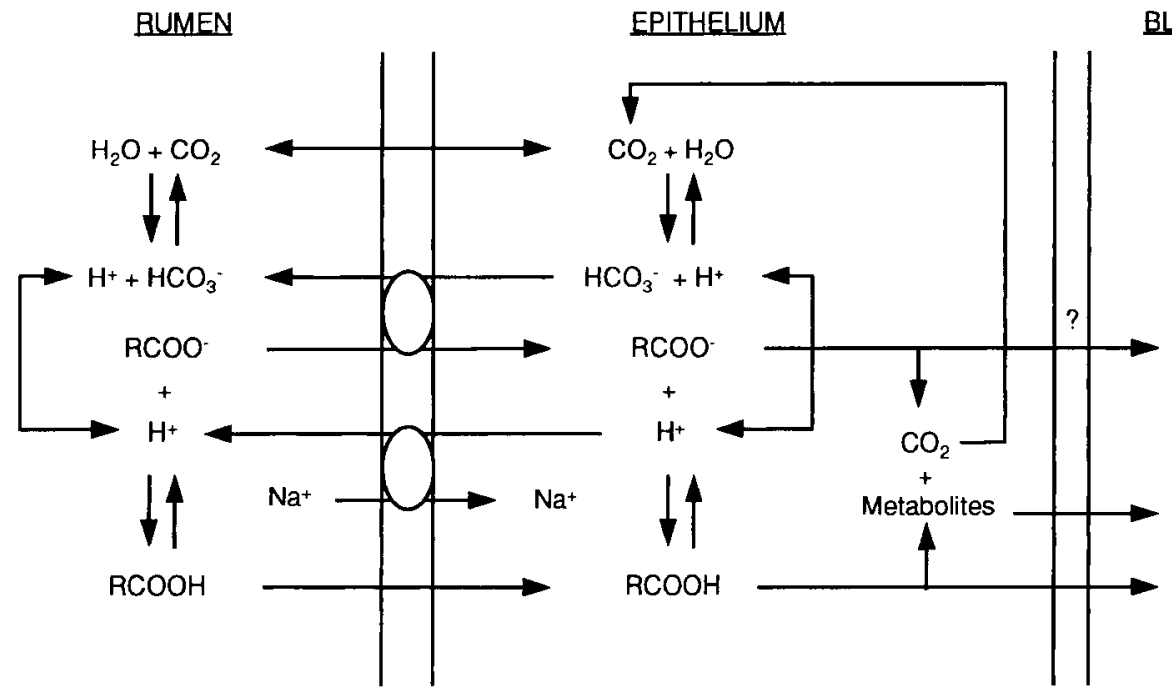

Fig 1. Diagram representing the different assumptions concerning the volatile fatty acid (VFA) absorption mechanisms across the ruminal epithelium (Stevens et al, 1986; Gäbel and Martens, 1991). 
As the concentration of non-ionised VFA in the rumen contents is low, conversion of the ionised to the non-ionised form close to the rumen wall will favour absorption. $\mathrm{A} \mathrm{pH}$ microclimate' has been observed near the epithelium of the distal colon of the guinea pig and rat (Rechkemer et al, 1979; McNeil and Ling, 1980). This local $\mathrm{pH}$ is stable and independent of the $\mathrm{pH}$ in the lumen bulk phase, but is close to neutral ( $\mathrm{pH} 6.4-6.9)$. Even if such a 'pH microclimate' exists near the rumen wall, the fraction of non-ionised VFA will still be tiny. Most of the models postulated for VFA absorption across the rumen wall involve protonation of VFA before they cross the apical pole of the epithelial cells. The protons may derive either from the hydration of $\mathrm{CO}_{2}$ from microbial fermentation, yielding $\mathrm{HCO}_{3}{ }^{-}$and $\mathrm{H}^{+}$, or from the $\mathrm{Na}^{+} / \mathrm{H}^{+}$exchanger present at the apical pole of the cells (Stevens et al, 1986). A link between the absorption of weak acids and the $\mathrm{Na}^{+} / \mathrm{H}^{+}$antiport has been observed by Gäbel and Martens (1991).

Inside the epithelial cells, a new equilibrium between the ionised and non-ionised forms of the VFA is set up in the local $\mathrm{pH}$ conditions. This tends to increase the nonionised VFA gradient across the apical membrane of the cells. This concentration gradient is accentuated by the intense intracellular catabolism of the VFA.

VFA output from the basal pole of the epithelial cells may take place by the same process as the input at the apical pole, that is, passive diffusion of the non-ionised form and assisted diffusion of the ionised form.

Studies in isolated rumens have shown that at acid pH (4.5-5.5), the VFA absorption rate increases with increasing chain length, or acetic < propionique < butyric acid, whereas at a $\mathrm{pH}$ close to neutral, the absorption rates of these three acids are very similar (Thorlacius and Lodge, 1973; Dijkstra et al, 1993). The absorption rates of VFA with branched chains also seem to be lower than those of their straight-chain isomers (Oshio and Tahata, 1984). These differences in absorption rates may be due to solubility differences in the lipid layers of the cell membranes, differences in VFA absorption mechanisms (different degrees of carrier involvement) and differences in the extent of VFA metabolism in the epithelial cell (cf review Rémond et al, 1995).

\section{Ammonia}

The ammonia in the rumen derives mainly from deamination of amino acids released during the breakdown of food, microbial and endogenous proteins, together with the hydrolysis of endogenous urea and any present in food. Loss of ammonia from the rumen can occur by incorporation into microbial proteins or absorption through the rumen wall ( 35 to $65 \%$ of the ammonia loss from the rumen), or by export from the rumen with the digestive contents $(10 \%$ of the loss) (Nolan and Stachiw, 1979; Siddons et al, 1985; Obara et al, 1991). Loss of ammonia by absorption through the rumen wall can thus be quantitatively very high. This absorption was first clearly demonstrated by McDonald in 1948. Since then, numerous studies have been carried out to try to determine the mechanisms governing this absorption.

Ammonia is a weak base with a pKa of 9 (Leng and Nolan, 1984). The HendersonHasselbach equation shows that at $\mathrm{pH}$ values between 6 and 7 , practically all the ammonia will be in its ionised form (99.9 and $98.7 \%$, respectively), that is, in the form that will diffuse poorly across the lipid layers of the cell membranes. At $\mathrm{pH}$ values near neutral, the ammonia absorption increases with the intraruminal ammonia concentration (Hogan, 1961; Bödeker et al, 1990; Rémond et al, 1993b). When the intraruminal $\mathrm{pH}$ is lowered (at constant ammonia concentration), the ammonia flux across the rumen wall is depressed (Hogan, 1961; 
Chalmers et al, 1971; Bödeker et al, 1990). At an acid $\mathrm{pH}$, the ammonia absorption remains stable despite the increase in intraruminal ammonia concentration (Hogan, 1961). These findings are generally taken as evidence that ammonia absorption across the epithelium of the rumen occurs by simple diffusion of the non-ionised form $\left(\mathrm{NH}_{3}\right)$. The possibility of ammonium ion $\left(\mathrm{NH}_{4}{ }^{+}\right)$absorption from the digestive contents has also been considered (Hogan, 1961; Siddons et al, 1985) but as this form is weakly lipid-soluble, its movement across the membranes of the epithelial cells would require the assistance of carriers. According to Bödeker (1994), a system able to transport $\mathrm{NH}_{4}{ }^{+}$is present in the rumen epithelial. The quantitative importance of this absorption route remains to be assessed.

In the short term, the absorption of ammonia thus depends mainly on the concentration of $\mathrm{NH}_{3}$ near the epithelium. The VFA and the $\mathrm{CO}_{2}$ in the rumen can modulate this dependency and favour ammonia absorp- tion (Bödeker et al, 1992b, Rémond et al, $1993 b)$. Several suggestions have been made concerning the action of these two variables. For Bödeker et al (1992a, b; fig 2), the interaction between the VFA and the absorption of ammonia may occur after the apical membrane of the epithelial cells. Since the $\mathrm{pH}$ inside these cells is close to 7 , the VFA absorbed in their non-ionised form will dissociate and release protons which can be used to form $\mathrm{NH}_{4}{ }^{+}$from the absorbed $\mathrm{NH}_{3}$. This process would result in a decrease in the intracellular $\mathrm{NH}_{3}$ concentration and thereby favour its absorption. Likewise, the intracellular release of $\mathrm{HCO}_{3}{ }^{-}$and $\mathrm{H}^{+}$from $\mathrm{CO}_{2}$ and $\mathrm{H}_{2} \mathrm{O}$ by the action of carbonic anhydrase could serve as a proton source for $\mathrm{NH}_{4}{ }^{+}$formation (Bödeker et al, 1992a). At each stage in its diffusion across the epithelium, the $\mathrm{NH}_{3}$ thus equilibrates with $\mathrm{NH}_{4}{ }^{+}$ according to the prevailing $\mathrm{pH}$, right through to the blood compartment.

The effects of VFA and $\mathrm{CO}_{2}$ on ammonia absorption may also be explained by their

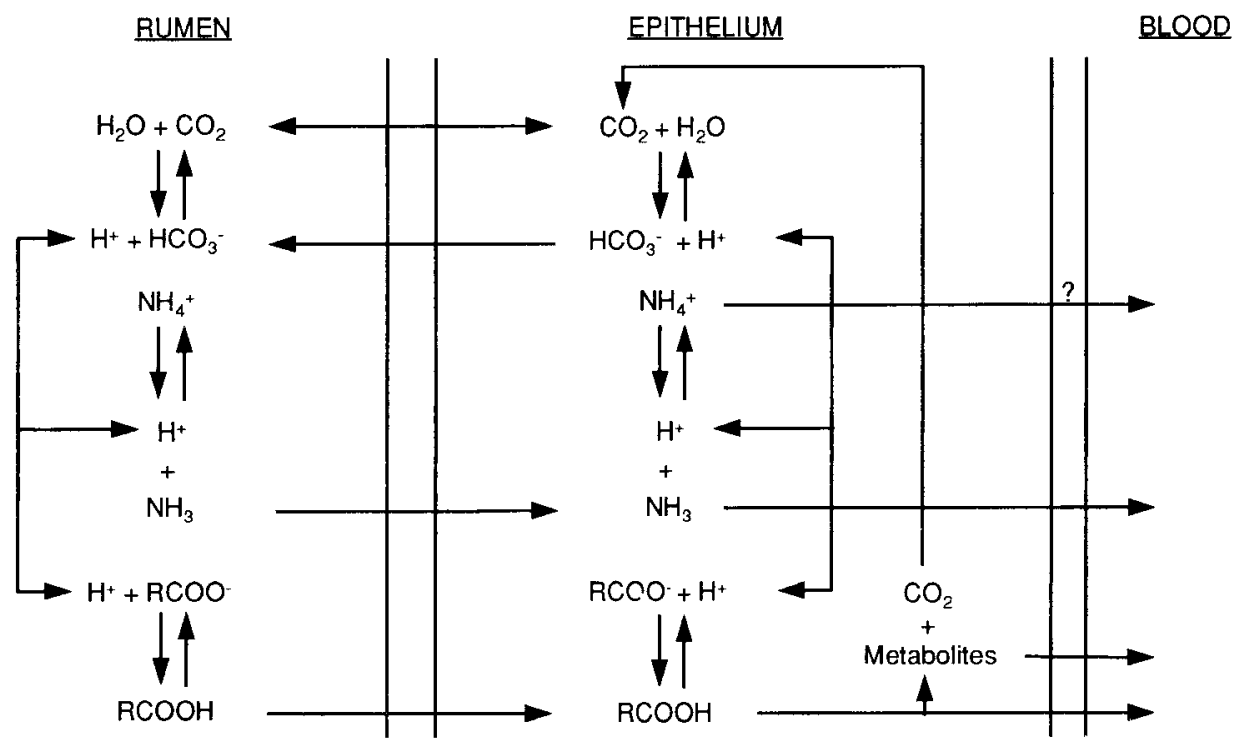

Fig 2. Diagram representing the different assumptions concerning the $\mathrm{NH}_{3}$ absorption mechanisms across the ruminal epithelium (Bödeker et al, 1992a, b). 


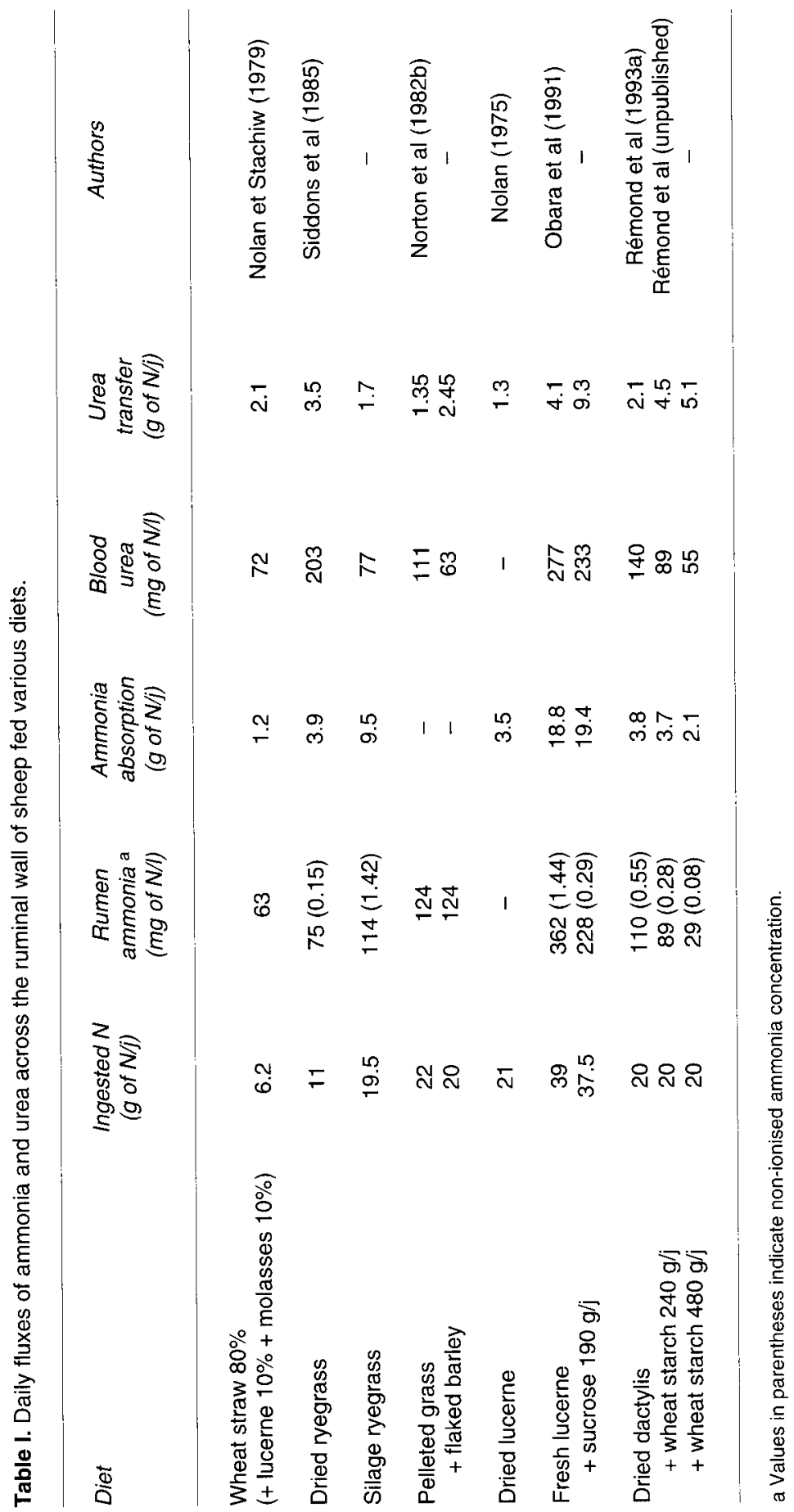


action on the subepithelial blood flow (Dobson, 1979) and irrigated capillary surface area (Thorlacius, 1972). Rémond et al (1993b) observed that when butyric acid was supplied to the rumen contents or when $\mathrm{CO}_{2}$ was blown in, the increase in ammonia flux across the rumen wall was always lower than the increase in ruminal blood flow produced by either of the two treatments. The increase in blood flow rate favours the absorption of substances by reducing their concentration in the interstitial fluid steeping the capillaries. It is therefore highly likely that the effect of VFA and $\mathrm{CO}_{2}$ on ammonia absorption involves both biochemical regulation linked to the $\mathrm{NH}_{3}-\mathrm{NH}_{4}{ }^{+}$equilibrium within the different cell layers in the epithelium, and regulation linked to ammonia elimination in the interstitial fluid via capillary circulation.

The daily absorption of ammonia from the rumen has been recorded in sheep under various feeding conditions (table I). The quantitative data available in the literature are, however, too sparse to accurately predict the daily fluxes from quantities of ingested nitrogen or intraruminal ammonia concentrations. In contrast to what the results of Siddons et al (1985) might suggest, it is difficult to establish a linear relationship between ammonia absorption and $\mathrm{NH}_{3}$ concentrations in the rumen. Given the extent of the modifications to the absorption capacity of the rumen (surface area $x$ permeability of epithelium) according to diet, particularly when this is rich in rapidly fermentable energy sources, it is not surprising that under these conditions, the variations in absorption cannot be wholly explained by variations in the concentration gradient between the rumen and the blood, and hence the variations in intraruminal $\mathrm{NH}_{3}$.

\section{Urea}

Since the work of Simmonet et al (1957), numerous studies have shown that blood urea can diffuse across the rumen epithelium. This process is nutritionally beneficial for the ruminant, since the bacteria present in the rumen are able to use the urea nitrogen to synthesise proteins, the amino acids of which will subsequently be available for postruminal absorption. The quantities of nitrogen recycled in this way vary widely ( 1 to $9 \mathrm{gN} /$ day in sheep), and may account for 5 to $25 \%$ of the nitrogen ingested (table I).

The work of Houpt and Houpt (1968) showed that urea transfer across the rumen wall was linearly related to the rumen-blood concentration gradient, and it has been generally accepted that urea crosses the ruminal epithelium by simple diffusion. Intraruminal hydrolysis of urea by bacterial ureases therefore facilitates the movement of urea through the rumen wall by maintaining a concentration gradient favourable to diffusion. Hence, it has been shown that the inhibition of urease activity in the rumen causes a decrease in the transepithelial flux of urea (Houpt and Houpt, 1968; Rémond et al, 1993b). In addition, the urea flux is dependent on the permeability of the epithelium. Since damage to the structure of the stratum corneum results in a marked increase in urea transport, urea diffusion seems to be strongly limited by the low permeability of this epithelial layer (Houpt and Houpt, 1968). Modifications to the exchange surfaces between the blood and rumen contents may also affect the quantitative extent of urea transport.

When the feed is supplemented with a rapidly fermentable energy source (sucrose, extruded barley, wheat starch), the daily flux of urea across the rumen wall can be doubled (table I), and the capacity of the epithelium to eliminate blood urea (the transepithelial urea flux relative to arterial urea flux) can be multiplied by four (Rémond et al, unpublished data). As the blood urea level decreases when these energy supplements are added, the increase in urea flux must be mainly due to modified epithelial surface 
area and permeability, in response to intraruminal VFA levels. The intraruminal urease activity increases when the feed is supplemented with rapidly fermentable carbohydrates (Cook, 1976); it could thus also be implicated in the long-term regulation of urea flux. Kennedy et al (1981) observed an increase in the number of facultative anaerobic bacteria adhering to the rumen wall when the diet was supplemented with glucose. However, a regulating effect of the epithelial urease activity on urea transfer still has not been firmly demonstrated. In addition, the intraruminal urease activity always seems to be in excess relative to the influx of urea in the rumen (Norton et al, 1982a; Whitelaw et al, 1991). Since the urease activity associated with the epithelium is generally greater than that of the rumen fluid (Wallace et al, 1979; Rybosova et al, 1984), its involvement in the long-term regulation of urea flux is controversial.

The transfer of urea across the rumen wall varies in the course of a feeding cycle (Rémond et al, 1993a), and so is evidently governed by a system of short-term regulation. Bubbling $\mathrm{CO}_{2}$ in the rumen significantly increases urea flux across the rumen wall (Thorlacius et al, 1971; Engelhardt et al, 1978; Rémond et al, 1993b). Likewise, increasing the butyric acid concentration in an isolated pouch of the rumen favours urea transfer (Engelhardt et al, 1978). The action of these two intraruminal factors does not involve modifications to the ruminal urease activity (Thorlacius et al, 1971; Rémond et al, 1993b). Although $\mathrm{CO}_{2}$ and butyric acid stimulate subepithelial blood flow (Dobson, 1984), the permeability of the capillary walls to urea is too low for the blood flow to affect urea diffusion (Landis and Pappenheimer, 1963). In addition, according to the results of Dobson et al (1971), urea clearance seems virtually independent of blood flow. VFA and $\mathrm{CO}_{2}$ could affect the amount of epithelial surface irrigated by acting on the closing of anastomoses between arterial and venous capillaries, and the opening of precapillary sphincter. This suggestion of a regulation of urea flux by the amount of exchange surface is supported by the results of Thorlacius (1972), according to which $\mathrm{CO}_{2}$ and VFA considerably increase the volume of blood present in the ruminal papillae.

Increasing intraruminal ammonia concentration decreases the urea flux across the rumen wall (Engelhardt et al, 1978; Rémond et al, 1993b). According to Rémond et al (1993b), the ammonia absorption may be responsible for reducing urea flux. The effect of ammonia on urease activity is long term (Cheng and Wallace, 1979) rather than short term, and the mechanism by which ammonia regulates the transepithelial flux of urea during short-term variations is not yet known. The work of Hörnicke et al (1972) showed that the ammonia absorption can modify haemodynamics in the ruminal mucosa; this could also explain the effect of ammonia on urea transfer.

The main factors acting on urea transfer through the ruminal epithelium, and their modes of action, are summarized in figure 3. Other factors may also be involved in the regulation of transepithelial urea flux. Increasing osmotic pressure in an isolated pouch of the rumen with mannitol (Houpt, 1970) stimulates urea transfer. However, Rémond et al (1993b) raised the intraruminal osmotic pressure with $\mathrm{NaCl}$ injections, and observed no effect on urea flux despite a lowering of the water absorption from the rumen. Under normal feeding conditions, the osmotic pressure seems to have little effect on urea transfer. Hormonal regulation of the urea flux has also been considered. According to Houpt (1970), vasopressin may modify the permeability of the rumen wall to urea. However, Thorlacius et al (1971) observed no modification of the urea clearance in response to a vasopressin injection. The work of Harrop and Phillipson (1970) and Rémond et al (1993b) also 
Short-term effect

Long-term effect

(adaptation to diet)

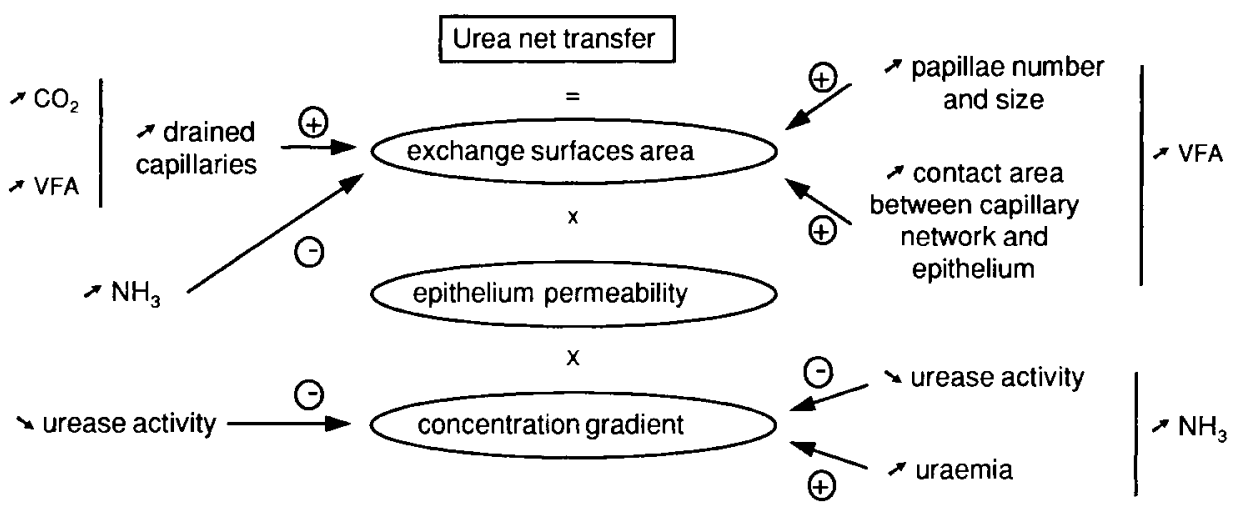

Fig 3. Intraruminal factors having short- or long-term effects on the urea flux across the ruminal epithelium, and the assumptions concerning their actions.

suggests that gastrin might play a role in the regulation of the urea flux across the rumen wall.

\section{Amino acids}

The absorption of free amino acids across the rumen wall was first observed by Demaux et al (1961). The permeability of this epithelium to amino acids has since been confirmed, with different methods, by Cook et al (1965) and Leibholz (1971a, b). The work of Webb et al (1992) even suggests permeability to peptides of a small size.

The concentrations of free amino acids in the rumen are generally very low (Annison, 1956; Williams and Cockburn, 1991). They vary during the course of a feeding cycle, peaking $1 \mathrm{~h}$ after ingestion of a meal (Leibholz, 1969; Williams and Cockburn, 1991). During this period, for diets rich in nitrogen, free amino acid concentrations in the rumen can exceed those in the plasma, resulting in passive diffusion through the ruminal epithelium (Leibholz, 1969). For most diets, the absorption of free amino acids from the rumen is, however, slight, given their very low levels there.

The concentrations of peptides in the rumen are higher than those of free amino acids. These concentrations vary according to the origin of the food proteins, peaking about $1 \mathrm{~h}$ after feeding (Williams and Cockburn, 1991). The possibility of peptide absorption from the rumen by passive diffusion cannot, therefore, be ruled out (Webb et al, 1992).

\section{Vitamins}

The work of Rérat et al (1958b) has shown that the rumen wall is also permeable to $\mathrm{B}$ group vitamins. Permeability to vitamin B1 seems extremely low, however (Höller et al, 1977). Although the vitamin concentrations in the rumen are high under normal feeding conditions, it is unlikely that the rumen is a major absorption site for $\mathrm{B}$ vitamins (Rérat et al, 1958a) since these are mainly located inside microorganisms and so are not available for absorption (Rérat 
et al, 1958b). With heavy supplementation, this absorption can become significant, as shown for niacin, which is absorbed mainly as nicotinamide (Erickson et al, 1991).

\section{TRANSEPITHELIAL MOVEMENT OF WATER AND MINERALS}

\section{Water}

There is very little quantitative data concerning the net water transfer across the rumen wall. From the differences observed between inflow through the oesophagus and outflow through the reticulo-omasal orifice, Warner and Stacy (1968) estimated that water absorption from the rumen could vary in the sheep from $50 \mathrm{~mL} / \mathrm{h}$ at rest to $300 \mathrm{~mL} / \mathrm{L}$ during the hours following water intake. Using the isolated rumen method, combined with the use of tritiated water, Willes et al (1970) observed that for sheep fed cut lucern hay twice daily, this absorption ranged from 300 to $800 \mathrm{~mL} / \mathrm{h}$, the highest values being observed 2 to $3 \mathrm{~h}$ after feeding. Comparable results ( 360 to $720 \mathrm{~mL} / \mathrm{h}$ peaking $1 \mathrm{~h}$ after feeding) were obtained by Rémond et al (1993a) in sheep fed chopped dactylis hay, calculating the water flux from the haemoglobin levels in the arterial and venous blood and the ruminal blood flow. The daily net flux of water during this experiment showed an absorption of $10 \mathrm{~L} /$ day. For sheep fed continuously with compressed feed, Faichney and Boston (1985) estimated the ruminal water absorption at $5 \mathrm{~L} /$ day. Ingestion of compressed feed results in a markedly lowered mastication time (ingestion plus rumination), which in turn results in a lower saliva secretion. The differences in saliva flow between the experiments of Faichney and Boston (1985) and Rémond et al (1993a) probably explain the differences in water flux observed through the rumen wall.
It is generally agreed that the main factor responsible for water movement through the ruminal epithelium is the osmotic gradient between the blood in the subepithelial region and the rumen contents. In contrast, the mechanism by which increasing ruminal butyric acid concentration causes an increase in water absorption through the rumen wall (Dobson et al, 1976; Rémond et al, 1993a) is controversial. The absorption of butyric acid may increase the rate of water absorption across the epithelium by causing an increase in ruminal blood flow (Dobson et al, 1976). Increasing the subepithelial blood flow, by a washout effect, would, however, tend to lower the concentration of solutes absorbed in the interstitial fluid and so reduce the osmotic pressure gradient between the digestive contents and the blood. The coupling of the absorption of sodium with that of VFA (Gäbel and Martens, 1991) may also explain the stimulating effect of butyric acid on water flow. This effect may thus be linked to modifications to the osmotic pressure gradient via regulation of the absorption of electrolytes such as sodium. By lowering the intraruminal $\mathrm{pH}$ with hydrochloric acid, Willes et al (1970) also observed an increase in water absorption across the rumen wall. This could also be explained by an increased VFA absorption (linked to the fall in $\mathrm{pH}$ ) or an increased absorption of $\mathrm{Cl}^{-}$supplied by $\mathrm{HCl}$. On injecting into the rumen two acids (butyric and acetohydroxamic) that can be absorbed through the rumen wall, increased water absorption was observed with or without increased blood flow (Rémond et al, $1993 b)$. Variations in water movement across the wall thus appear to be more closely linked to variations in electrolyte movement than to fluctuations in blood flow.

Dobson et al (1970) observed that $\mathrm{CO}_{2}$ stimulated water re-absorption from the ventral sac of the washed isolated rumen. Its mode of action was discussed by Dobson (1984), who suggested the existence of a 
counter-current exchange system that maintains high concentrations of bicarbonate and $\mathrm{CO}_{2}$ in the capillary blood, resulting in a high osmotic pressure. However, Rémond et al (1993b) showed that in a normally filled rumen, increasing the $\mathrm{CO}_{2}$ did not significantly modify the water flux across the wall. It may therefore be concluded that variations in $\mathrm{CO}_{2}$ concentration in the rumen have minimal impact on transepithelial water flow.

Finally, the rate of water absorption from the rumen is liable to vary according to the animal's state of hydration. Several researchers have shown that in dehydrated ruminants, the absorption is paradoxically much lower than in hydrated animals, despite an osmotic gradient that is particularly favourable to absorption (Silanikove, 1994). However, these observations are controversial and have not yet been satisfactorily explained.

\section{Minerals}

As in single-stomach animals, the intestine, and particularly the small intestine, was long considered to be the main or even exclusive site of mineral absorption from ruminants. Over the last 15 years, this assumption has been challenged for magnesium, for which the forestomachs are the main absoptive site in the gastrointestinal tract, and also for phosphorus, calcium, copper, iron and zinc for which absorption can occur before the duodenum (Kirk et al, 1994; Rahnema et al, 1994). Most of the quantitative results were obtained from calculating ruminal input/duodenal output balance. This type of method has the disadvantage of giving no indication of the exact absorptive site (reticulorumen, omasum, abomasum) and does not take into account the minerals introduced by the saliva which could mask possible absorption from the forestomachs.
The absorption of minerals in the digestive tract can involve several pathways. Practically all the mineral elements that are present in bioavailable forms can cross the walls of the digestive tract along an electrochemical gradient. This process is usually nonsaturatable and is not subject to any physiological or nutritional regulation. This transfer can also be facilitated by transport systems ( $\mathrm{Mg}, \mathrm{Na}, \mathrm{Cl}, \mathrm{P})$. It can also involve primary $(\mathrm{Ca}, \mathrm{Na})$ or secondary $(\mathrm{Mg})$ active transport involving energy consumption.

\section{Magnesium}

Magnesium absorption from the reticulorumen accounts for about $80 \%$ of its absorption from the entire digestive tract (Tomas and Potter, 1976). Many studies have shown that the efficiency of $\mathrm{Mg}$ absorption is strongly influenced by the physical and chemical conditions prevailing in the rumen. Thus, increasing intraruminal $\mathrm{K}$ concentration, or reducing that of $\mathrm{Na}$ produces a marked decrease in $\mathrm{Mg}$ absorption (reviews by Fontenot et al, 1989; Leonhard et al, 1989). Increasing the phosphate concentration favours $\mathrm{Mg}$ absorption (Beardsworth et al, 1989b). The results for the effect of increasing ammoniacal nitrogen are conflicting: a decrease, sometimes marked, in $\mathrm{Mg}$ absorption (Martens and Rayssiguier, 1980; Care et al, 1984; Martens et al, 1988) or no effect (Moore et al, 1972; Grings and Males, 1987). The experimental methods used probably partly account for these differences; the results of Moore et al (1972) and Grings and Males (1987) were obtained by the balance method on animals accustomed to a nitrogen-rich diet, while the studies showing an effect of $\mathrm{NH}_{3}$ concentration on $\mathrm{Mg}$ absorption were carried out by perfusing buffer solutions in isolated rumen pouches. The effect of $\mathrm{NH}_{3}$ concentration on $\mathrm{Mg}$ absorption therefore appears to be limited in time and it may occur at the time of 
the postprandial ruminal $\mathrm{NH}_{3}$ peak. The absence of any effect due to changes in diet may be linked to the adaptive mechanisms of the epithelium (Martens et al, 1991).

A fall in $\mathrm{pH}$ causes a drop in $\mathrm{Mg}$ absorption, which is less marked, however, in animals that have received a concentrate-rich diet (Gäbel et al, 1987). Increasing the intraruminal osmotic pressure from 240 to $367 \mathrm{mosmol} / \mathrm{L}$ (Martens, 1985) or from 315 to $422 \mathrm{mosmol} / \mathrm{L}$ (Gäbel et al, 1987) does not affect the $\mathrm{Mg}$ absorption, although it modifies the transepithelial flux of water.

The available energy in the rumen is a factor favouring $\mathrm{Mg}$ absorption. In particular, the VFA concentration is positively correlated with $\mathrm{Mg}$ absorption (Martens and Rayssiguier, 1980; Martens et al, 1988). Forage supplementation with starch (Thomson et al, 1984; Giduck and Fontenot, 1987), lactose (Rayssiguier and Poncet, 1980; Giduck and Fontenot, 1987) or glucose
(Giduck and Fontenot, 1987; Giduck et al, 1988 ), causes an appreciable increase in the ruminal $\mathrm{Mg}$ absorption. This effect observed in vivo is difficult to interpret since supplementation with fermentable energy substrates simultaneously produces modifications to $\mathrm{pH}$, and to VFA and $\mathrm{NH}_{3}$ concentrations, and modifications to the morphology of the epithelium.

In vitro studies of the mechanisms of $\mathrm{Mg}$ absorption have shown that this absorption results both from paracellular and transcellular diffusion of $\mathrm{Mg}$ along an electrochemical gradient, and from electroneutral transport that may take place via a $\mathrm{Mg}^{++} / 2 \mathrm{H}^{+}$ exchanger in the apical membranes (Martens et al, 1991; fig 4). The existence of an electrogenic diffusion mechanism provides an explanation for the inhibiting effect of $\mathrm{K}$ on $\mathrm{Mg}$ absorption. In vitro methods, which allow the $\mathrm{K}$ concentration and the transmembrane potential (ddpt) to be varied

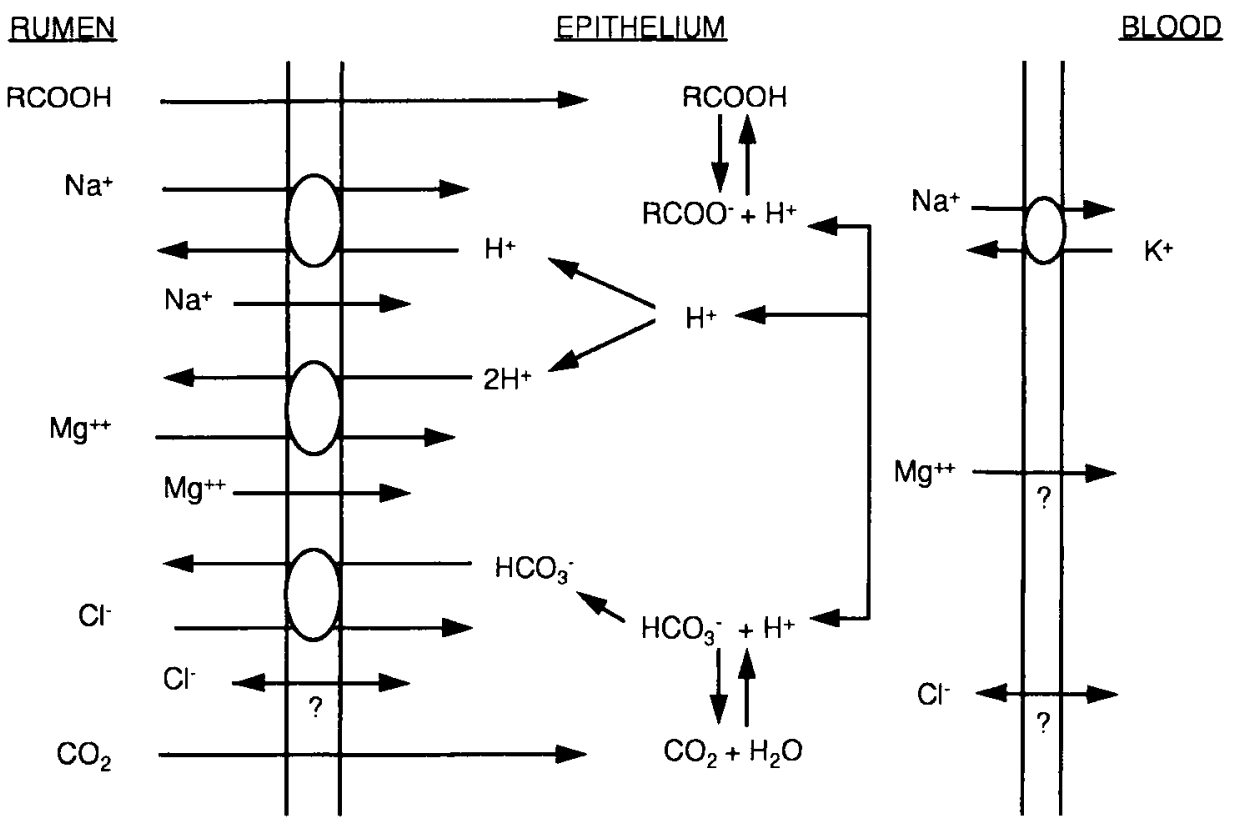

Fig 4. Model for the $\mathrm{Mg}, \mathrm{Na}$ and $\mathrm{Cl}$ transport processes in the ruminal epithelium (Gäbel and Martens, 1991; Martens et al, 1991). 
independently, have shown that the effect of $K$ is linked to an increase in the ddpt and not to a direct $K$ effect (Martens et al, 1987, 1991). An increase in intraruminal $\mathrm{K}$ may have several effects, reducing the paracellular diffusion of $\mathrm{Mg}$ by raising the ddpt, and reducing the transcellular diffusion by lowering ddpt in the apical membranes (Martens et al, 1991). Reduced Mg absorption resulting from a drop in intraruminal $\mathrm{pH}$ may also be explained by a decrease in ddpt linked to a decrease in Na/K-ATPase activity (Gäbel et al, 1987).

The electoneutral transport of $\mathrm{Mg}$ in the apical membranes depends on the intracellular proton concentration, itself partly determined by the amount of intracellular dissociation of the absorbed VFA and the hydration of $\mathrm{CO}_{2}$ (Martens et al, 1991). The absorption of $\mathrm{Mg}$ is therefore partly determined by the operation of the $\mathrm{Na} / \mathrm{K}$ pump in the basal membranes, which influences the ddpt values, and the operation of the electroneutral exchangers that evacuate intracellular $\mathrm{HCO}_{3}{ }^{-}$(Martens et al, 1991).

\section{Calcium}

The possibility of a net absorption of calcium by the ruminal epithelium is now firmly established. The quantitative importance of this absorption seems to depend on the concentration, form and solubility of the $\mathrm{Ca}$, and on the nutrient/Ca interactions.

The net transport of calcium through the rumen wall depends on the concentration of $\mathrm{Ca}^{++}$in the rumen: net secretion up to about $1 \mathrm{mmol}$ of $\mathrm{Ca}^{++}$per $\mathrm{L}$, and net absorption for higher concentrations (Höller et al, 1988a; Beardsworth et al, 1989a). Under physiological conditions, this concentration is situated between 1 and $4 \mathrm{mmol} / \mathrm{L}$ (Grings and Males, 1987; Höller et al, 1988a).

In addition, the net absorption of $\mathrm{Ca}$ is closely linked to the concentration of inorganic phosphate $(\mathrm{Pi})$ in the rumen (Höller et al, 1988b; Beardsworth et al, 1989b). A concentration of about $15 \mathrm{mmol} / \mathrm{L}$ of $\mathrm{Pi}$ is optimal for Ca absorption (Care et al,1989). This corresponds to the usual physiological values in animals with no $\mathrm{P}$ deficiency. In contrast, the absorption of $\mathrm{Ca}$ is correlated negatively with the $\mathrm{Mg}$ concentration in the rumen; an increase in the $\mathrm{Mg}$ concentration from 1 to $5 \mathrm{mmol} / \mathrm{L}$, spanning the normal physiological range of 2.6 to 3.5 (Grace et al, 1988), causes an appreciable decrease in Ca absorption (Care et al, 1989).

The absorption of $\mathrm{Ca}$ in the digestive tract takes place simultaneously by diffusion in the intercellular spaces and by transcellular movement. In the small intestine, the latter makes use of a three-stage process: diffusion through the apical membranes, transport inside the cytosol by a vitamin Ddependent $\mathrm{Ca}$ binding protein and primary active transport in the basal membranes. Less is known about the mechanisms of $\mathrm{Ca}$ absorption from the ruminal epithelium than about that of $\mathrm{Mg}$. In vitro studies indicated that the net flux of $\mathrm{Ca}$ is dependent upon active $\mathrm{Na}$ transport accomplished by the $\mathrm{Na} / \mathrm{K}$-ATPase system, and that the transepithelial fluxes consisted in both ddpt-dependent and ddpt-independent components (Höller et al, 1988a). Adding 1-25-dihydroxycholecalciferol increases the net absorption of Ca without, however, reducing serous-mucous transport in goats (Breves et al, 1989), suggesting, as at intestinal sites, a regulation of active $\mathrm{Ca}$ transport by this vitamin $\mathrm{D}$ metabolite.

\section{Sodium and chloride}

Large quantities of $\mathrm{Na}$ enter the rumen as sodium bicarbonate contained in saliva (from 3 to $3.5 \mathrm{~g} / \mathrm{L}$ of $\mathrm{Na}$ in animals with no deficiency); about $50 \%$ of the salivary $\mathrm{Na}$ is reabsorbed before the duodenum (Pfeffer et al, 1970; Gäbel and Martens, 1991). All the epithelia of the forestomachs display high $\mathrm{Na}$ absorptive capacities, but this 
capacity seems to be greatest in the rumen. Chloride is also absorbed in the rumen (Martens and Blum, 1987). The amount of $\mathrm{Cl}$ absorbed is about half that of $\mathrm{Na}$ (Gäbel et al, 1987).

The mechanisms of the preintestinal absorption of $\mathrm{Na}$ and $\mathrm{Cl}$ (fig 4) gave rise to a review (Gäbel and Martens, 1991). The absorption of $\mathrm{Na}$ in the rumen takes place against an electrochemical gradient (Gäbel et al, 1987). In vivo studies have not demonstrated any such mechanism for $\mathrm{Cl}$ insofar as the electrochemical gradient favours its passive absorption (Gäbel et al, 1989). The transfer of $\mathrm{Na}$ and $\mathrm{Cl}$ across the apical membrane of the epithelial cells responds to $\mathrm{Na}^{+} / \mathrm{H}^{+}$and $\mathrm{Cl}-/ \mathrm{HCO}_{3}{ }^{-}$ exchanges, respectively. The transfer of $\mathrm{Na}$ across the basal membrane involves an $\mathrm{Na} / \mathrm{K}-\mathrm{ATP}$ Tase system. The mechanism of the $\mathrm{Cl}^{-}$exit remains to be ascertained (Gäbel and Martens, 1991). In the rumen, the $\mathrm{Na}^{+} / \mathrm{H}^{+}$exchange may be stimulated by the absorption of weak acids, which would consequently affect the efficiency of $\mathrm{Na}$ absorption.

\section{Phosphorus}

For $\mathrm{P}$, most of the work done in vivo in sheep reports a net secretion of 1 to $15 \mathrm{~g} /$ day before the duodenum (Grace et al, 1974; BenGhedalia et al, 1975; Dillon and Scott, 1979; Greene et al, 1983; Wylie et al, 1985). These results vary widely according to the level of feeding and the $P$ return by the saliva. This abundant endogenous return by the saliva can mask a net $\mathrm{P}$ absorption through the ruminal epithelium (Breves et al, 1988; Yano et al, 1991), although this seems minor (Yano et al, 1991). The absorption of $P$ through this epithelium does not make use of active transport; it may take place via electroneutral transport or by simple transcellular or paracellular diffusion (Breves et al, 1988).

\section{Potassium}

The absorption of $\mathrm{K}$ in the different compartments of the ruminant's stomach is slight; $K$ is absorbed mainly in the small intestine (Kirk et al, 1994; Rahnema et al, 1994). This absorption does occur passively, the quantity absorbed being proportional to concentration. Inversion of flow can even occur if the $\mathrm{K}$ concentration is greater in the plasma than in the rumen.

\section{Sulphur}

A large fraction of the absorbed $S$ is absorbed from the rumen, mainly as sulphides derived from the reduction of food sulfates, or as inorganic $S$ resulting in particular from the breakdown of sulphur-containing amino acids by rumen microorganisms, especially sulphate-reducing bacteria. At the usual plasma $\mathrm{pH}$, the sulphides are very weakly dissociated. Absorption therefore concerns the nondissociated form (hydrogen sulphide), which is liposoluble. This absorption is rapid; the half-life of sulphides in the rumen is 10 to $22 \mathrm{~min}$ (Bray, 1969). It is a simple diffusion, directly related to the sulphide concentration in the medium (Bray and Till, 1975; Doyle and Moir, 1980). The quantity of $S$ absorbed as sulfate can be considered as negligible.

\section{Copper, iron and zinc}

The in vivo balances indicate that the absorption of $\mathrm{Cu}, \mathrm{Fe}$ and $\mathrm{Zn}$ mainly takes place before the duodenum (Kirk et al, 1994). The quantitative importance of this absorption through the rumen epithelium, and the mechanisms involved are still unknown.

\section{CONCLUSION}

This review shows that the rumen cannot be reduced to a simple microbial fermenta- 
tion compartment, but that it is also the site for the exchange of numerous substances through the rumen wall. This exchange can take the form of either absorption from the rumen or, less often, diffusion into the rumen from the blood. Numerous studies have shown that the anatomical, histological and functional characteristics of the rumen mucosa enable these exchanges.

The most recent studies have focused in particular on evaluating the extent of these transfers in vivo, and, using in vitro methods, on ascertaining the mechanisms involved in these transfers through the rumen wall.

Through the absorptive capacities of its wall, the rumen thus plays an important role in helping to provide some of the ruminant's energy (absorption of VFA), water and mineral needs. In addition, the absorption process ensures a certain homeostasis of the rumen contents, by preventing excessive build-up of VFA and ammonia. This also enables the rumen to participate in recycling processes of varying complexity, for example, of urea or certain minerals, through rumen-saliva cycles.

Finally, it is quite clear that absorption through the rumen wall can constitute a good in vivo and in vitro model for the study of general mechanisms of digestive absorption.

\section{REFERENCES}

Annison EF (1956) Nitrogen metabolism in the sheep. Protein digestion in the rumen. Biochem $J 64,705-$ 714

Barcroft J, McAnally RA, Phillipson AT (1944) Absorption of volatile acids from the alimentary tracts of the sheep and other animals. J Exp Biol 20, 120-129

Barnes RJ, Comline RS, Dobson A (1983) Changes in the blood flow to the digestive organs of sheep induced by feeding. $Q J$ Exp Physiol 68, 77-88

Barnes RJ, Comline RS, Dobson A (1986) The control of splanchnic blood flow. In: Control of digestion and metabolism in ruminants (LP Milligan, WL Grovum,
A Dobson, eds), Reston Publishing Co, Reston, VA, USA, Chapter 3

Beardsworth LJ, Beardsworth PM, Care AD (1989a) Calcium fluxes across the wall of the ovine reticulorumen in vitro. Res Vet Sci 47, 404-405

Beardsworth LJ, Beardsworth PM, Care AD (1989b) The effect of phosphate concentration on the absorption of calcium phosphorus and magnesium from the reticulo-rumen of the sheep. Br J Nutr 61, 715-723

Ben-Ghedalia D, Tagari H, Zamwel S, Bondi A (1975) Solubility and net exchange of calcium magnesium and phosphorus in digesta flowing along the gut of sheep. Br J Nutr 33, 87-94

Bergman EN (1990) Energy contributions of volatile fatty acids from the gastrointestinal tract in various species. Physiol Rev 70, 567-590

Bödeker D (1994) Participation of $\mathrm{NH}_{4}{ }^{+}$in ammonia transport across sheep rumen epithelium. Proc SoC Nutr Physiol 3, 89

Bödeker D, Shen $Y$, Höller $H(1990)$ Influence of short chain fatty acids and $\mathrm{HCO}_{3}$ - on ammonia absorption through the sheep rumen wall. In: Proceedings of the Third International Symposium on the Nutrition of Herbivores. MSAP, Malaysia, 36

Bödeker D, Oppelland G, Höller H (1992a) Involvement of carbonic anhydrase in ammonia flux across rumen mucosa in vitro. Exp Physiol 77, 517-519

Bödeker D, Shen Y, Kemskowski J, Höller H (1992b) Influence of short-chain fatty acids on ammonia absorption across the rumen wall of sheep. Exp Physiol 77, 369-376

Bray AC (1969) Sulphur metabolism in sheep. II. The absorption of inorganic sulphate and inorganic sulphide from the sheep's rumen. Austr $J$ Agric Res 20, 739-749

Bray AC, Till AR (1975) Metabolism of sulphur in the gastro-intestinal tract. In: Digestion and metabolism of ruminants (IW McDonald, ACI Warner, eds), University of New England, Armindale, Australia, 243-260

Breves G, Höller H, Packheiser P, Gäbel G, Martens H (1988) Flux of inorganic phosphate across the sheep rumen wall in vivo and in vitro. $Q J$ Exp Physiol 73 , 343-351

Breves G, Gäbel G, Pfeffer E, Martens H (1989) Unidirectional calcium fluxes across the isolated rumen mucosa of goats as affected by $125-(\mathrm{OH})$-D3. Proc Nutr Soc 48, 163A

Care AD, Brown RC, Farrar AR, Pickard DW (1984) Magnesium absorption from the digestive tract of sheep. $Q J$ Exp Physiol 69, 577-587

Care AD, Beardsworth LJ, Beardsworth PM, Breves G (1989) The absorption of calcium and phosphate from the rumen. Acta Vet Scand 86, 152-158

Chalmers MI, Jaffray AE, White F (1971) Movements of ammonia following intraruminal administration of urea or casein. Proc Nutr Soc 30, 7-17 
Cheetham SE, Steven DH (1966) Vascular supply of the absorptive surface of the ruminant stomach. J Physio/ 186, 56P

Cheng KJ, Wallace RJ (1979) The mechanism of passage of endogenous urea through the rumen wall and the role of ureolytic epithelial bacteria in the urea flow. Br J Nutr 42, 553-557

Cheng KJ, Costerton JW (1980) Adherent rumen bacteria - their role in the digestion of plant material, urea and epithelial cells. In: Digestive physiology and metabolism in ruminants ( $Y$ Ruckebusch, $P$ Thivend, eds), MTP Press, Lancaster, 227-250

Colin G (1853) Physiologie comparée des animaux domestiques, tome I. Baillière, Paris, $667 p$

Cook AR (1976) Urease activity in the rumen of sheep and the isolation of ureolytic bacteria. $J$ Gen Microbiol $92,32-48$

Cook RM, Brown RE, Davis CL (1965) Protein metabolism in the rumen. I. Absorption of glycine and other amino acids. J Dairy Sci $48,475-483$

Demaux G, Le Bars $H$, Molle J, Rérat A, Simonnet $H$ (1961) Absorption des acides aminés au niveau du rumen, de l'intestin grêle et du cæcum chez le mouton. Bull Acad Vet Fr 34, 85-88

Dijkstra J, Boer $\mathrm{H}$, van Bruchem J, Bruining M, Tamminga $S$ (1993) Absorption of volatile fatty acids from the rumen of lactating dairy cows as influenced by volatile fatty acid concentration, $\mathrm{pH}$ and rumen liquid volume. Br J Nutr 69, 385-396

Dillon J, Scott D (1979) Digesta flow and mineral absorption in lambs before and after weaning. J Agric SCl 92, 289-297

Dobson A (1979) The choice of models relating tritiated water absorption to subepithelial blood flow in the rumen of sheep. J Physiol 297, 111-121

Dobson A (1984) Blood flow and absorption from the rumen. $Q J$ Exp Physiol 69, 599-606

Dobson A, Sellers AF, Shaw GT (1970) Absorption of water from isolated ventral sac of rumen of the cow. J App/ Physiol 28, 100-104

Dobson A, Sellers AF, Thorlacius SO (1971) Limitation of diffusion by blood flow through bovine ruminal epithelium. Am J Physiol 220, 1337-1343

Dobson A, Sellers AF, Gatewood VH (1976) Absorption and exchange of water across rumen epithelium. Am J Physiol 231, 1588-1594

Doyle PT, Moir RJ (1980) Sulfur and methionin metabolism in sheep. IV. Metabolism and absorption in the intestines. Aust J Biol Sci 33, 303-307

von Engelhardt W, Hales JRS (1977) Partition of capillary blood flow in rumen, reticulum, and omasum of sheep. Am J Physio/ 232, E53-E56

von Engelhardt W. Hinderer S, Wipper E (1978) Factors influencing the endogenous urea- $\mathrm{N}$ secretion and utilization in the gastrointestinal tract. In: Ruminants digestion and feed evaluation (DF Osbourn, DE
Beever, DJ Thomson, eds), Agriculture Research Council, London, UK, 4.1-4.12

Erickson PS, Murphy MR, McSweeney CS, Trusk AM (1991) Niacin absorption from the rumen. J Dairy Sci 74, 3492-3495

Faichney GJ, Boston RC (1985) Movement of water within the body of sheep fed at maintenance under thermoneutral conditions. Aust J Biol Sci 38, 85-94

Fell BF, Weekes TEC (1975) Food intake as a mediator of adaptation in the ruminal epithelium. In: Digestion and metabolism in the ruminant (IW McDonald, ACI Warner, eds), University of New England, Armidale, NSW, 2351, Australia, 101-118

Fontenot JP, Allen VG, Bunce GE, Goff JP (1989) Factors influencing magnesium absorption and metabolism in ruminants. J Anim Sci67, 3445-3455

Gäbel G, Martens H (1991) Transport of $\mathrm{Na}$ and $\mathrm{Cl}$ across the forestomach epithelium: mecanisms and interactions with short chain fatty acids. In: Proceedings of the VIlth international symposium on ruminant physiology, Sendai 1989, Academic Press, London, UK, 129-147

Gäbel G, Martens H, Suendermann M, Galfi P (1987) The effect of diet intraruminal $\mathrm{pH}$ and osmolarity on sodium chloride and magnesium absorption from the temporarily isolated and washed reticulo-rumen of sheep. Q J Exp Physiol and Cognate Medical Sciences 72, 501-511

Gäbel G, Bell M, Martens H (1989) The effect of low mucosal $\mathrm{pH}$ on sodium and chloride movement across the isolated rumen mucosa of sheep. $Q J$ Exp Physiol 74, 35-44

Galfi P, Neogrady S, Sakata T (1991) Effects of volatile fatty acids on the epithelial cell proliferation of the digestive tract and its hormonal mediation. In: Physiological aspects of digestion and metabolism in ruminants (T Tsuda, Y Sasaki, R Kwashima, eds), Academic Press, San Diego, CA, USA, 49-59

Giduck SA, Fontenot JP (1987) Utilization of magnesium and others macrominerals in sheep supplemented with different readily-fermentable carbohydrates. J Anim Sci 65, 1667-1673

Giduck SA, Fontenot JP, Rahnema SH (1988) Effect of ruminal infusion of glucose volatile fatty acids and hydrochloric acid on mineral metabolism in sheep. JAnim Sci66, 532-542

Goodlad RA (1981) Some effects of diet on the mitotic index and the cell cycle of the ruminal epithelium of sheep. $Q J$ Exp Physiol 66, 487-495

Grace ND, Ulyatt MJ, MacRae JC (1974) Quantitative digestion of fresh herbage by sheep. III. The movement of $\mathrm{Mg}, \mathrm{Ca}, \mathrm{P}, \mathrm{K}$ and $\mathrm{Na}$ in the digestive tract. $J$ Agric Sci 82, 321-330

Grace ND, Caple IW, Care AD (1988) Studies in sheep on the absorption of magnesium from a low molecular weight fraction of the reticulo-rumen contents. $\mathrm{Br}$ J Nutr 59, 93-108 
Greene LW, Fontenot JP, Webb KE (1983) Site of magnesium and other macromineral absorption in steers fed high levels of potassium. J Anim Sci 57, 503510

Grings EE, Males JA (1987) Effects of potassium on macromineral absorption in sheep fed wheat strawbased diets. J Anim Sci 64, 872-879

Harrop CJF, Phillipson AT (1970) The effect of diet and pentagastrin on the influx of urea into the rumen of sheep. Proc Nutr Soc 30, 3A

Henrikson RC (1970) Ultrastructure of ovine ruminal epithelium and localization of sodium in the tissue. $J$ Uitrastruct Res 30, 385-401

Henrikson RC, Stacy BD (1971) The barrier to diffusion across ruminal epithelium: a study by electron microscopy using horseradish peroxidase, lanthanum, and ferritin. J Ultrastruct Res 34, 72-82

Hogan JP (1961) The absorption of ammonia through the rumen of the sheep. Aust J Biol Sci 14, 448-460

Höller H, Fecke M, Schaller K (1977) Permeability to thiamin of the sheep rumen wall in vitro. J Anim $\mathrm{SCl}$ 44, 158-161

Höller H, Breves G, Kocabatmaz M, Gerdes H (1988a) Flux of calcium across the sheep rumen wall in vivo and in vitro. $Q J$ Exp Physiol 73, 609-618

Höller H, Breves G, Dubberke M (1988b) Flux of inorganic phosphate and calcium across the isolated mucosa of the sheep omasum. $J$ Vet Med Series $A$ 35, 709-716

Hörnicke H, Ehrlein HJ, Engelhardt WV (1972) Hämodynamische wirkungen intraruminaler ammoniakgaben bei zeigen. Zentralb/Veterinarmed [A] 19, $822-842$

Houpt TR (1970) Transfer of urea and ammonia to the rumen. In: Physiology of digestion and metabolism in the ruminant (AT Phillipson, ed), Oriel Press, Newcastle-upon-Tyne, UK, 119-131

Houpt TR, Houpt KA (1968) Transfer of urea nitrogen across the rumen wall. Am J Physiol 214, 12961303

Kennedy PM, Milligan LP (1980) The degradation and utilisation of endogenous urea in the gastrointestinal tract of ruminants: a review. Can J Anim Sci60, 205221

Kennedy PM, Clarke RTJ, Milligan LP (1981) Influences of dietary sucrose and urea on tranfer of endogenous urea to the rumen of sheep and number of epithelial bacteria. Br J Nutr 46, 533-541

Kirk DJ, Fontenot JP, Ranhema S (1994) Effects of feeding lasolacid and monensin on digestive tract flow and partial absorption of minerals in sheep. $J$ Anim Sci 72, 1029-1037

Kramer T, Gürtler H, Gäbel G (1994) Interactions between short chain fatty acids, sodium, and chloride during their absorption from the reticulorumen of sheep. Proc Soc Nutr Physiol 3, 82
Landis EM, Pappenheimer JR (1963) Exchanges of substances through the capillary walls. In: Handbook of physiology (WF Hamilton, ed), American Physiological Society, Washington, DC, USA, Vol II

Leibholz J (1969) Effect of diet on the concentration of free amino acids, ammonia and urea in the rumen liquor and blood plasma of the sheep. J Anim Sci $29,628-633$

Leibholz $\mathrm{J}$ (1971a) The absorption of amino acids from the rumen of the sheep. 1. The loss of amino acids from solutions placed in the washed rumen in vivo. Aust J Agric Res 22, 639-645

Leibholz J (1971b) The absorption of amino acids from the rumen of the sheep. 2 . The transfer of histidine, glycine, and ammonia across the rumen epithelium in vitro. Aust J Agric Res 22, 647-653

Leng RA, Nolan JV (1984) Symposium: Protein nutrition of the lactating dairy cows. J Dairy Sci67, 10721089

Leonhard S, Martens H, Gäbel G (1989) New aspects of magnesium transport in ruminants. Acta Vet Scand 86, 146-151

Mailman D (1982) Blood flow and intestinal absorption. Fed Proc 41, 2096-2100

Martens $\mathrm{H}$ (1985) Magnesium absorption from the temporarily isolated rumen of sheep. The effect of water absorption and osmotic pressure. Zentralb/ Veterinarmed [A] 32, 631-635

Martens H, Rayssiguier Y (1980) Magnesium metabolism and hypomagnesaemia. In: Proceedings of the digestive physiology and metabolism in ruminants. AVI Publishing Co, Westport, CT, USA, 117-466

Martens H, Blum I (1987) Studies on the absorption of sodium and chloride from the rumen of sheep. Comp Bioch Physiol [A] 86, 653-656

Martens H, Harmeyer J, Michael H (1978) Magnesium transport by isolated rumen epithelium. Res Vet $\mathrm{Sci}$ 24,161-168

Martens H, Gäbel G, Strozyk H (1987) The effect of potassium and the transmural potential difference on magnesium transport across an isolated preparation of sheep rumen epithelium. $Q J$ Exp Physiol 72, 181-188

Martens $\mathrm{H}$, Heggeman $\mathrm{G}$, Regier K (1988) Studies on the effect of $\mathrm{K}, \mathrm{Na}, \mathrm{NH}_{4}{ }^{+}$, VFA and $\mathrm{CO}_{2}$ on the net absorption of magnesium from the temporarily isolated rumen of heifers. J Vet Med 35, 73-80

Martens H, Leonhard S, Gäbel G (1991) Minerals and digestion: exchanges in the digestive tract. In: fumen microbial metabolism and ruminant digestion (JP Jouany, ed), INRA, Éditions, Paris, France, 192216

McCowan RP, Cheng KJ, Costerton JW (1980) Adherent bacterial population on the bovine rumen wall: distribution patterns of adherent bacteria. Appl Environ Microbio/ 39, 233 
McDonald IW (1948) The absorption of ammonia from the rumen of the sheep. Biochem J 42, 584-587

McGavin MD, Morrill JL (1976) Scanning electron microscopy of ruminal papillae in calves fed various amounts and forms of roughage. Am J Vet Res 37, 497-508

McNeil NI, Ling KLE (1980) The mucosal surface $\mathrm{pH}$ of the large intestine. Gastroenterology 78,1220

Méot F, Boivin R (1994) Rumen motility and ruminal blood flow in sheep. Proc Soc Nutr Physio/3, 9

Moore WF, Fontenot JP, Webb KE (1972) Effect of form and level of nitrogen on magnesium utilisation. $J$ Anim Sci 35, 1046-1053

Nocek JE, Herbein JH, Polan CE (1980) Influence of ration physical form, ruminal degradable nitrogen and age of rumen epithelial propionate and acetate transport and some enzyme activities. J Nutr 110 , 2355-2364

Nolan JV (1975) Quantitative models of nitrogen metabolism in sheep. In: Digestion and metabolism in the ruminant (IW McDonald, $\mathrm{ACI}$ Warner, eds), University of New England, Armidale, Australia, 416-431

Nolan JV, Leng RA (1972) Dynamic aspects of ammonia and urea metabolism in sheep. Br J Nutr 27, 177194

Nolan JV, Stachiw S (1979) Fermentation and nitrogen dynamics in Merino sheep given a low-quality roughage diet. $\mathrm{Br} J$ Nutr $42,63-80$

Nolan JV, Krebs GL, Hennessy DW (1987) Aspects of protein nutrition and metabolism in ruminants. In: Isotope-aided studies on nonprotein nitrogen and agroindustrial byproducts utilization by ruminants. IAEA, Vienna, Austria, 1-17

Norton BW, Janes AN, Armstrong DG (1982a) The effect of intraruminal infusions of sodium bicarbonate, ammonium chloride and sodium butyrate on urea metabolism in sheep. Br J Nutr 48, 265-274

Norton BW, Mackintosh JB, Armstrong DG (1982b) Urea synthesis and degradation in sheep given pelletedgrass diets containing flaked barley. $\mathrm{Br} J$ Nutr 48 , 249-264

Obara Y, Dellow DW, Nolan JV (1991) Effects of energyrich supplements on nitrogen kinetics in ruminants. In: Physiological aspects of digestion and metabolism in ruminants ( $T$ Tsuda, $Y$ Sasaki, $R$ Kwashima, eds), Academic Press, San Diego, CA, USA, 515-539

Oshio S, Tahata I (1984) Absorption of dissociated volatile fatty acids through the rumen wall of sheep. Can J Anim Sci 64 (suppl), 167-168

Peters JP, Shen RYW, Robinson JA, Chester ST (1990) Disappearance and passage of propionic acid from the rumen of beef steer. J Anim Sci 68, 3337-3349

Peters JP, Shen RYW, Robinson JA (1992) Disappearance of acetic acid from the bovine reticulorumen at basal and elevated concentrations of acetic acid. $J$ Anim Sci 70, 1509-15i7
Pfeffer E, Thomson A, Armstrong DG (1970) Studies on intestinal digestion in the sheep. 3. Net movement of certain inorganic elements in the digestive tract on rations containing different proportions of hay or rolled barley. Br J Nutr 24, 197-204

Rahnema S, Wu Z, Ohajuruka W, Weis WP, Palmquist DL (1994) Site of mineral absorption in lactating cows fed high-fat diets. J Anim Sci 72, 229-235

Rayssiguier $Y$, Poncet $C$ (1980) Effect of lactose supplement on digestion of lucerne hay by sheep. II. Absorption of magnesium and calcium in the stomach. J Anim Sci 51, 186-192

Rechkemmer G, Ronnau K, Kuschinsky W, Engelhardt WV (1979) $\mathrm{pH}$-microclimate at the surface of the intestine of guinea-pig and rat. Pfluegers Arch 382, R31 (abstr)

Rémond D (1992) Echanges d'azote uréique et ammoniacal à travers la paroi du rumen de mouton : cinétique, bilan journalier et mécanismes de régulation. Thèse $n 467$, univ Clermont-Ferrand-II, France

Rémond D, Chaise JP, Delval E, Poncet C (1993a) Net flux of metabolites across the rumen wall of sheep fed twice a day with orchardgrass hay. J Anim Sci 71, 2529-2538

Rémond D, Chaise JP, Delval E, Poncet C (1993b) Net transfer of urea and ammonia across the rumen wall of sheep. J Anim Sci 71, 2785-2792

Rémond D, Poncet C, Lefaivre $J(1993 c$ ) Technical note: Ruminal vein catheterization and continuous blood flow measurement in ruminal arteries of sheep. J Anim Sci 71, 1276-1280

Rémond D, Ortigues I, Jouany JP (1995) Energy substrates for the ruminal epithelium. Proc Nutr Soc 54, 95-105

Rérat A, Le Bars H, Molle J (1958a) Utilisation d'une méthode de perfusion pour la mise en évidence de l'absorption des vitamines $B$ chez le mouton normalement alimenté. Compt Rend Acad Sci 246 , 1920-1922

Rérat A, Molle J, Le Bars H (1958b) Mise en évidence chez le mouton de la perméabilité du rumen aux vitamines $\mathrm{B}$ et conditions de leur absorption à ce niveau. Compt Rend Acad Sci 246, 2051-2054

Rybosova E, Javorsky P, Havassy I, Horsky K (1984) Urease activity of adherent bacteria in the sheep rumen. Physiologia Bohemoslovaca 33, 411-416

Sakata T, Tamate H (1974) Effect of the intermittent feeding on the mitotic index and the ultrastructure of basal cells of the ruminal epithelium in the sheep. Tohoku J Agric Res 27, 133

Sakata T, Tamate H (1978) Rumen epithelial cell proliferation accelered by rapid increase in intraruminal butyrate. J Dairy Sci61, 1109-1113

Sakata T, Tamate H (1979) Rumen epithelium cell proliferation accelered by propionate and acetate. J Dairy Sci62, 49-52 
Sellers AF, Stevens CE, Dobson A, McLeod FD (1964) Arterial blood flow to the ruminant stomach. $A m J$ Physio/ 207, 371-377

Siciliano-Jones J, Murphy MR (1989) Production of volatile fatty acids in the rumen and cecum-colon of steers as affected by forage:concentrate and forage physical form. J Dainy Sci 72, 485-492

Siddons RC, Nolan JV, Beever DE, Macrae JC (1985) Nitrogen digestion and metabolism in sheep consuming diets containing contrasting forms and levels of N. Br J Nutr 54, 175-187

Silanikove N (1994) The struggle to maintain hydratation and osmoregulation in animals experiencing severe deshydration and rapid deshydration: the story of ruminants. Exp Physiol 79, 281-300

Simmonet H, Le Bars H, Mollé J (1957) Le cycle de l'urée administrée par voie buccale chez les ruminants. Compt Rend Acad Sci 244, 943-945

Steven DH, Marshall AB (1970) Organization of the rumen epithelium. In: Physiology of digestion and metabolism in the ruminant (AT Phillipson, ed), Oriel Press, Newcastle-upon-Tyne, UK, 80-100

Stevens CE, Argenzio RA, Roberts MC (1986) Comparative physiology of the mammalian colon and suggestions for animal models of human disorders. Clin Gastroenterol 15, 763-786

Sydney J, Lyford J (1988) Growth and development of the ruminant digestive system. In: The ruminant animal: digestive physiology and nutrition (DC Church, ed), A Reston Book, Prentice Hall, Canada Inc, Toronto, ON, Canada, 44-63

Tamate H, Sakata T (1979) Epithelium-propria interface of ruminant forestomach. Ann Rech Vet 10, 482-484

Tamate H, Kikuchi T, Sakata T (1974) Ultrastructural changes in the ruminal epithelium after fasting and subsequent refeeding in the sheep. Tohoku J Agric Res 25, 142-155

Thomson JK, Gelman AL, Jessiman CS (1984) Effect of digestible carbohydrates on the apparent absorption of magnesium by wether lambs. Can J Anim Sci $64,219-220$

Thorlacius SO (1972) Effect of steam-volatile fatty acids and carbon dioxyde on blood content of rumen papillae of the cow. Am J Vet Res 33, 427-430

Thorlacius SO, Lodge GA (1973) Absorption of steamvolatile fatty acids from the rumen of the cow as influ- enced by diet, buffers, and pH. Can J Anim Sci 53 , 279-288

Thorlacius SO, Dobson A, Sellers AF (1971) Effect of carbon dioxyde on urea diffusion through bovine ruminal epithelium. Am J Physiol 220, 162-170

Titus E, Ahearn GA (1992) Vertebrate gastrointestinal fermentation: transport mechanisms for volatile fatty acids. Am J Physiol 262, R547-R553

Tomas FM, Potter BJ (1976) The site of magnesium absorption from the ruminant stomach. Br J Nutr 36 , 37-45

Wallace RJ, Cheng KJ, Dinsdale D, Ørskov ER (1979) An independent microbial flora of the epithelium and its role in the ecomicrobiology of the rumen. Nature $279,424-426$

Warner ACl, Stacy BD (1968) The fate of water in the rumen. 2. Water balances throughout the feeding cycle in sheep. Br J Nutr 22, 389-410

Webb KE, Matthews JC, DiRienzo DB (1992) Peptide absorption: a review of current concepts and future perspectives. J Anim Sci 70, 3248-3257

Weigand E, Young JW, McGilliard AD (1975) Volatile fatty acids metabolism by rumen mucosa from cattle fed hay or grain. J Dairy Sci $58,1294-1300$

Weston $\mathrm{RH}$, Hogan JP (1968) The digestion of pasture plants by sheep. 1. Ruminal production of volatile fatty acids by sheep offered diets of ryegrass and forage oats. Aust J Agric Res 19, 419-432

Whitelaw FG, Milne JS, Wright SA (1991) Urease (EC 3.5.1.5) inhibition in the sheep rumen and its effect on urea and nitrogen metabolism. BrJ Nutr 66, 209-225

Willes RF, Mendel VE, Robblee AR (1970) Water transfer from the reticulo-rumen of sheep. J Anim Sci 31, 85-91

Williams AP, Cockburn JE (1991) Effect of slowly and rapidly degraded protein sources on the concentrations of amino acids and peptides in the rumen of steers. J Sci Food Agric 56, 303-314

Wylie MJ, Fontenot JP, Greene LW (1985) Absorption of magnesium and other macrominerals in sheep infused with potassium in different parts of the digestive tract. J Anim Sci 61, 1219-1229

Yano F, Yano H, Breves G (1991) Calcium and phosphorus metabolism in ruminants. In: Proceedings of the VIIth international symposium on ruminant physiology, Sendail 1989. Academic Press, London, UK, 277-291 